\title{
KESEHATAN
}

\section{ANAK DAN BALITA}

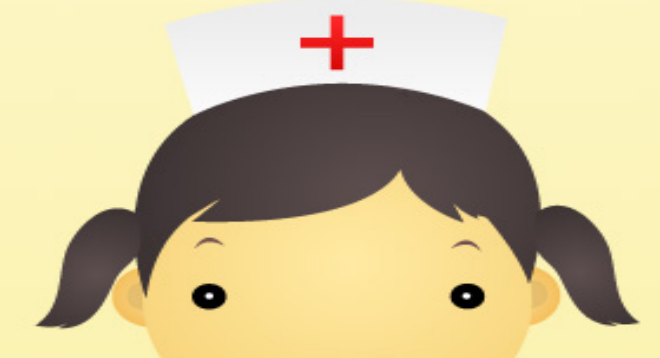

Ikrima Auliyah Rustam

70200120092 


\section{KESEHATAN ANAK}

- Masalah kesehatan anak adalah permasalahan global yang terjadi hingga di Indonesia. Tidak hanya menimpa kota-kota besar, namun juga sampai ke pelosok Indonesia.

- Setiap tahun lebih dari sepertiga kematian anak di dunia berkaitan dengan masalah kurang gizi.

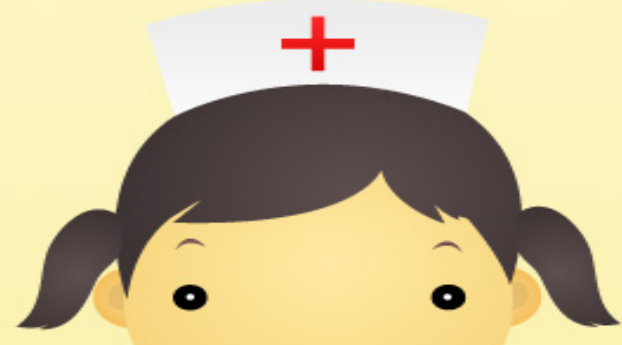

- Jumlah kematian bayi dari tahun 2016 - 2020 memiliki nilai yang fluktuatif. Nilai tertinggi terjadi pada tahun 2018 sebesar 138 bayi yang meninggal, di Tahun 2020 jumlah kematian bayi mencapai 115 jiwa nilai ini mengalami peningkatan dari tahun sebelumnya yang hanya mencapai 108 jiwa. (Profil Kesehatan RI,2020) 


\section{KESEHATAN ANAK}

- Salah satu cara untuk memecahkan permasalahan tentang kesehatan anak adalah dengan meningkatkan wawasan dan pengetahuan tentang apa yang terjadi pada fase hidup seorang anak, bahkan sejak si kecil masih bayi.

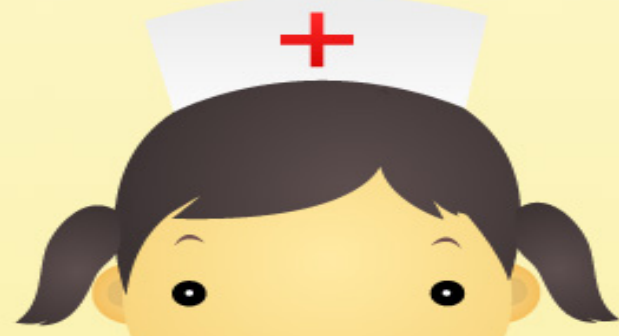

- Balita adalah anak yang telah menginjak usia di atas satu tahun. Para ahli menggolongkan usia balita sebagai tahapan perkembangan anak yang cukup rentanterhadap berbagai serangan penyakit, termasuk penyakit yang disebabkan oleh kekurangan atau kelebihan asupan nutrisijenis tertentu. 


\section{Masalah-masalah Kesehatan Anak dan Balita}

- ISPA

- Diare

- Stunting

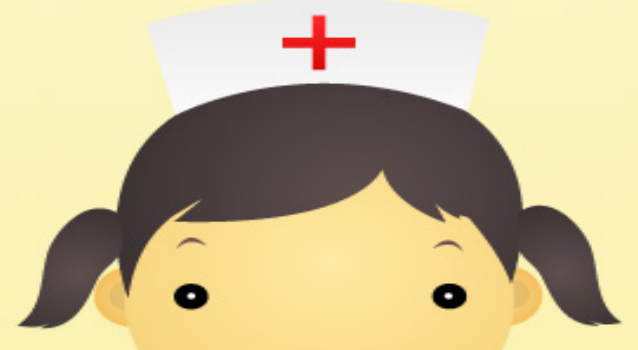

- Cacar air

- Cacingan

- Demam

- Kejang

- dll 


\section{Faktor Penyebab Masalah Kesehatan Anak}

- Faktor Lingkungan

Tidak adanya Kepemilikan jamban di setiap rumah, kurangnya ketersediaan air bersih dan tempat pembuangan sampah dan air limbah.

- Faktor Perilaku

minum air mentah, berak tidak di jamban dankebiasaan tidak mencuci tangan dengan sabun sebelum makan maupun sesudah buang air.

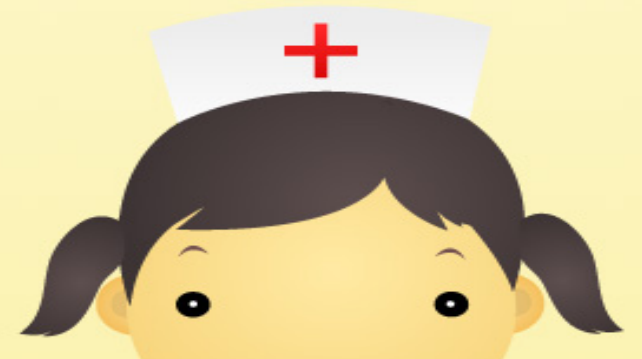

- Faktor Kebudayaan

Kebudayan mengunyahkan makanan kepada anak/balita, yang dapat menyebabkan berbagai gangguan kesehatan pada anak. 


\section{Faktor Penyebab Masalah Kesehatan Anak}

- Faktor Ekonomi

Ketahanan pangan keluarga , MP-ASI, Makanan Tambahan bergizi untuk anak

- Faktor Pendidikan

Faktor pendidikan orang tua yang secara tidak

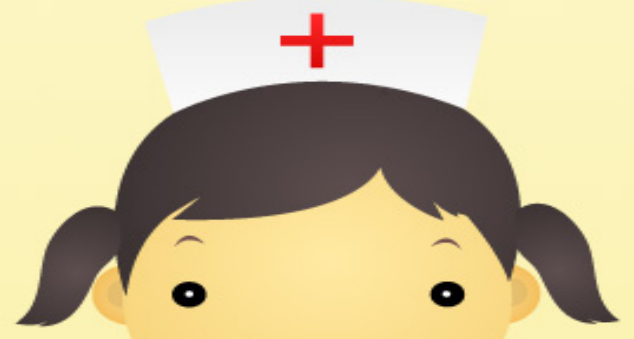
langsung mempengaruhi status gizi anak, terutama dalam periode seribu hari pertama kehidupan (HPK) 
1) $x_{0}<x<4$

1) 零

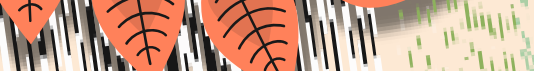

-

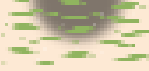

\section{Cara menjaga Kesehatan anak \& Pelayanan kesehat Neonatal}

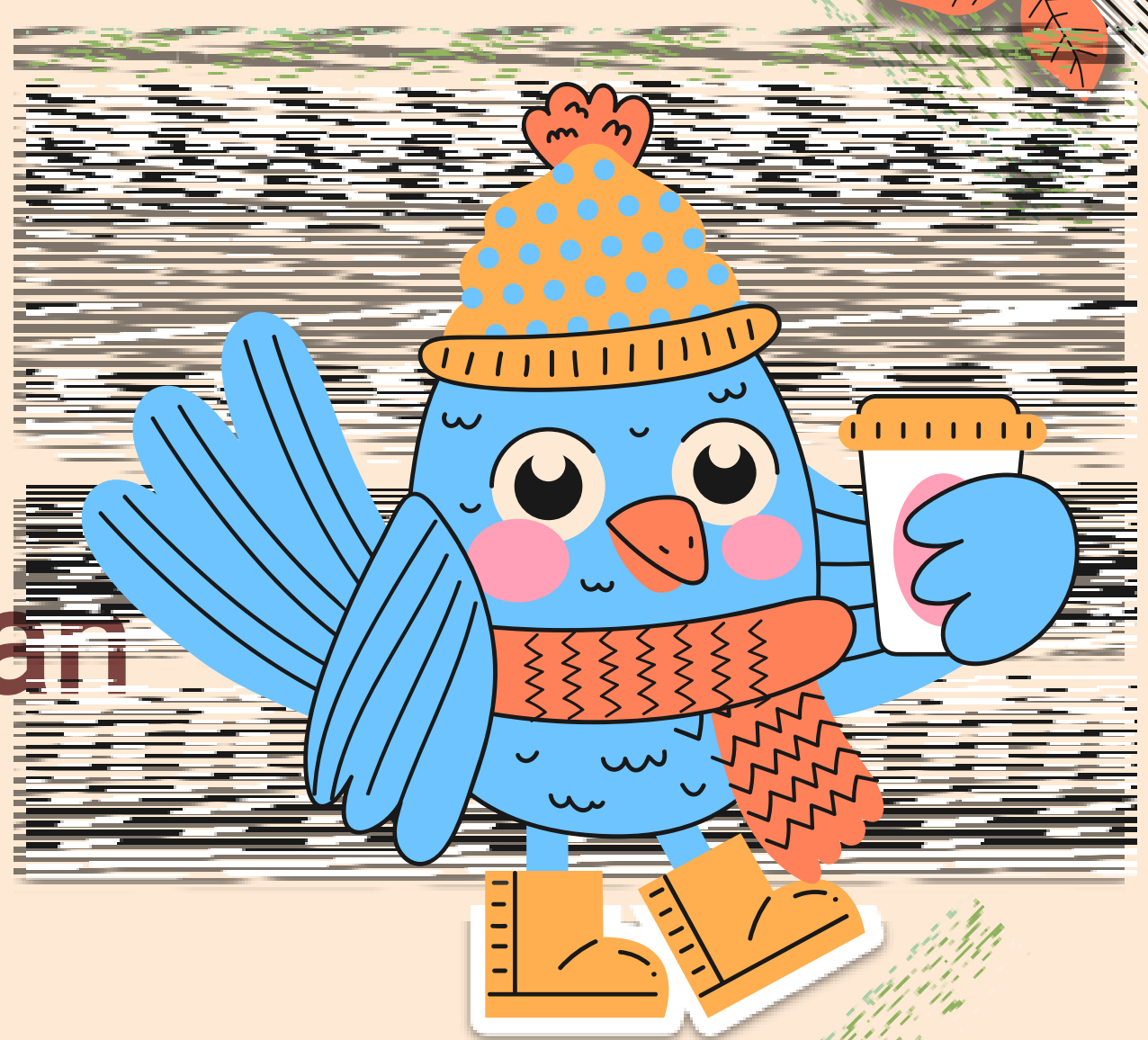




\section{Cara menjaga kesehatan anak}

Banyak faktor yang perlu diperhatikan dalam menjaga kesehatan anak.

Namun, mencegah penyakit lebih baik daripada mengobati. 


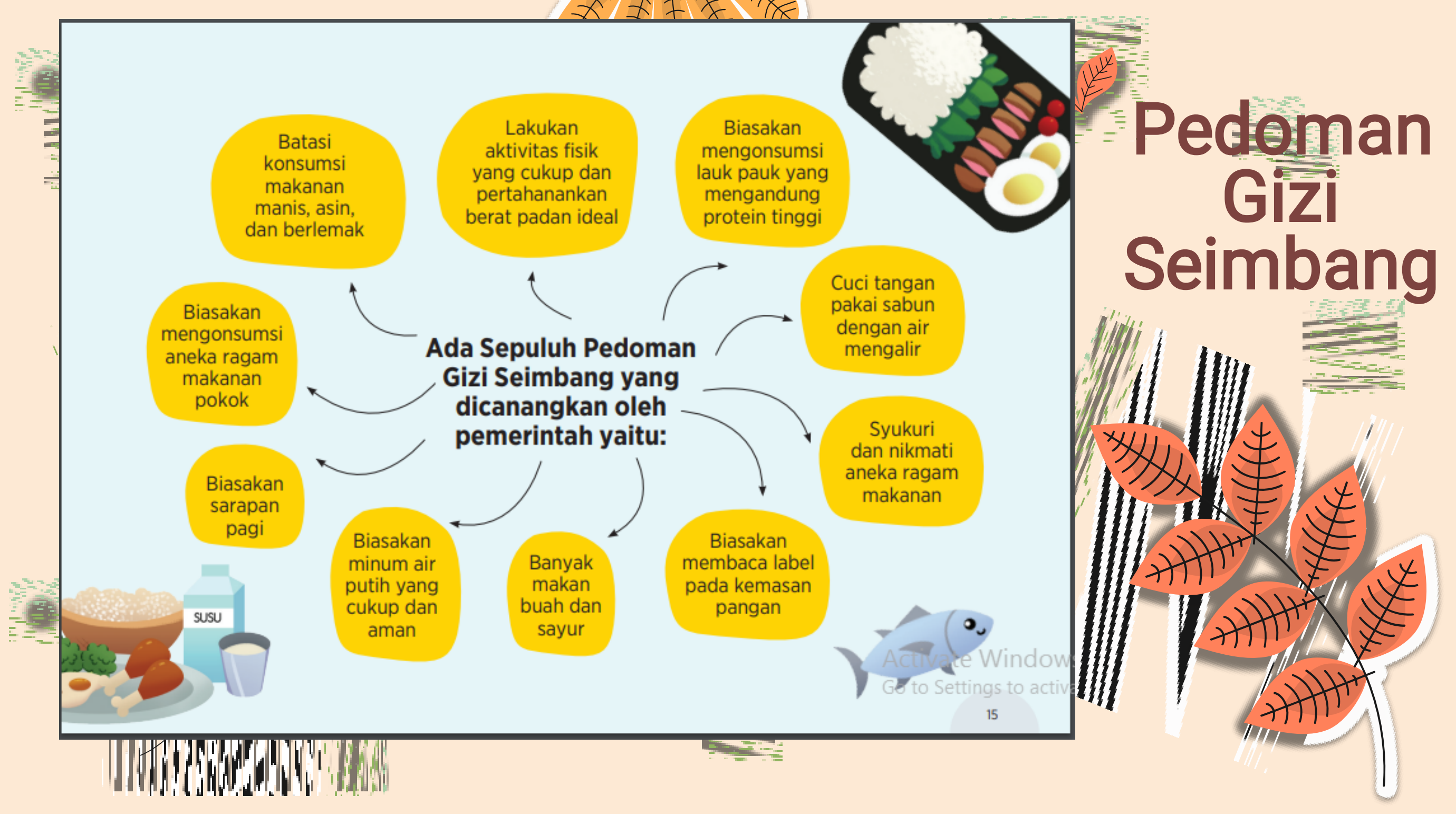




\section{Menjaga kebérsihan anak.}

Kebersihan mulut Kebersihan kuku Kebersihan tubuh Kebersihan tangan Kebersihan kaki Menjaga kebersihan setelah menggunakan toilet Menjaga kebersihan saat batuk dan bersin Kebersihan dalam rumah Kebersihan dalam rumah

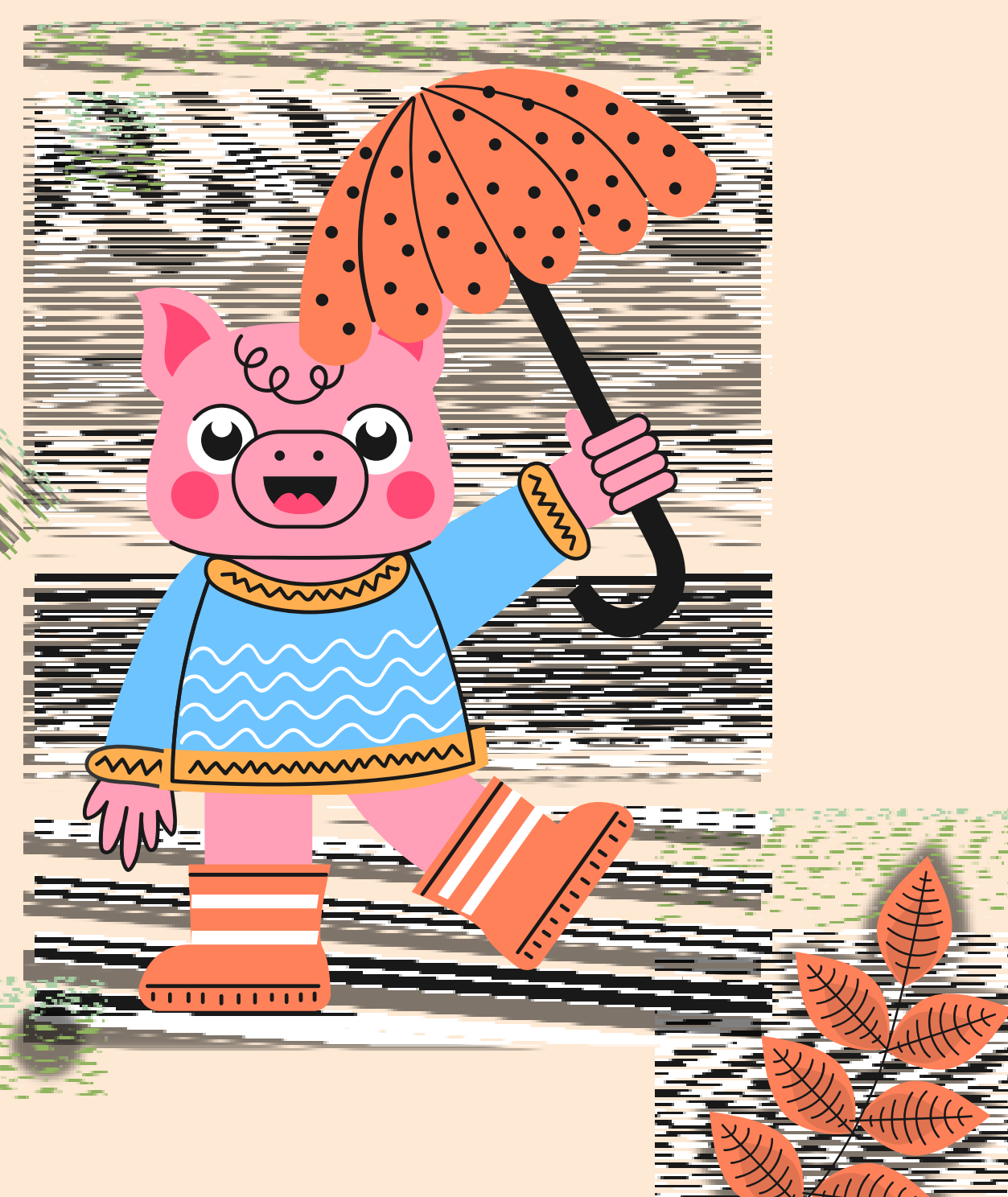




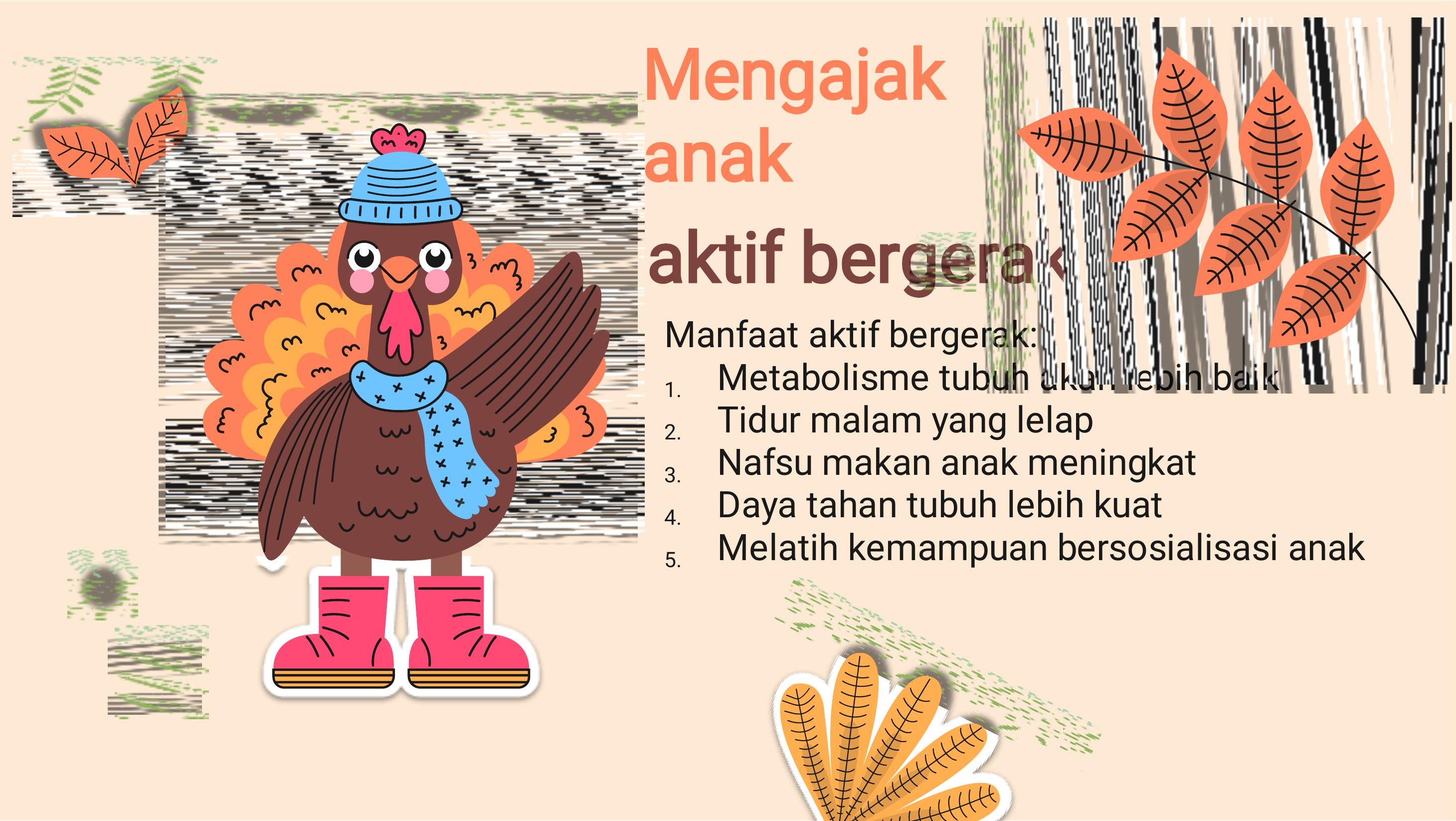




\section{Mematuhi jadwal imunisasi}

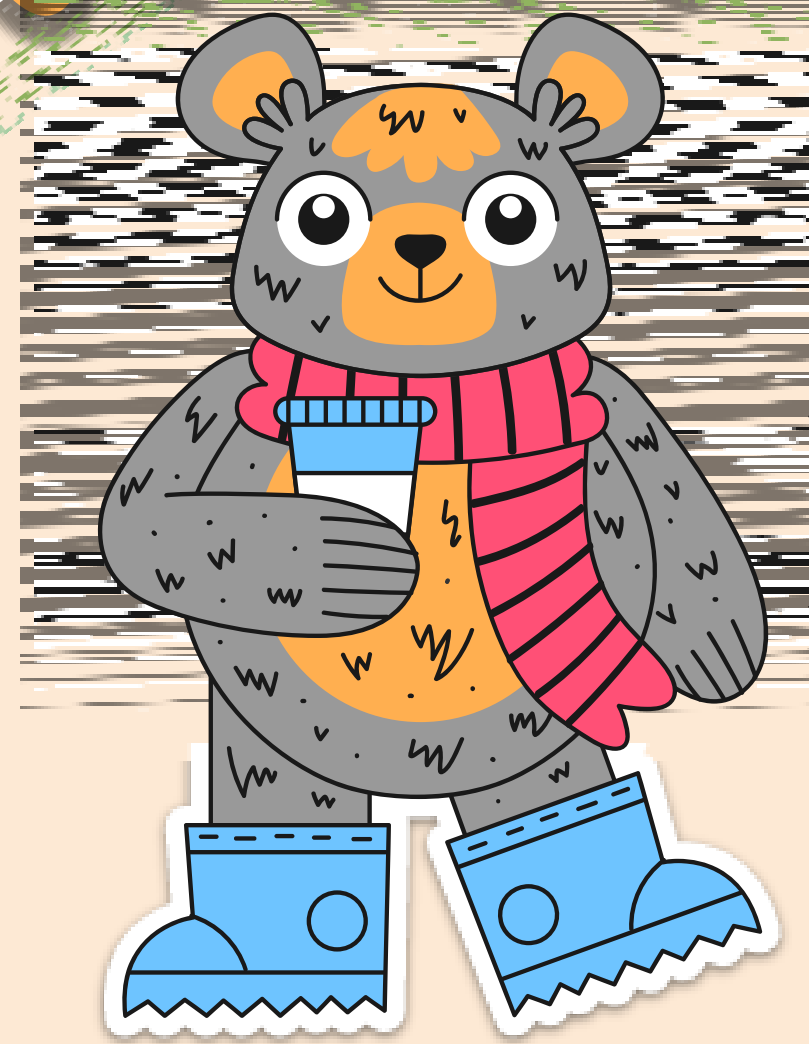

fek Samping Imunisasi

Imunisasi bisa disertai efek samping, biasa disebut Kejadian kutan Pasca Imunisasi (KIPI). Efek samping ini antara lain demam ingan sampai tinggi, atau nyeri dan bengkak di area bekas suntikan, yang membuat anak rewel. Namun, reaksi ini akan mereda dalam 3-4 hari. Ikatan Dokter Anak Indonesia (IDAI) merekomendasikan beberapa aksin dalam program imunisasi:

1. Hepatitis B

2. Polio

3. DPT

4. BCG

5. Hib

6. Campak

7. MMR 


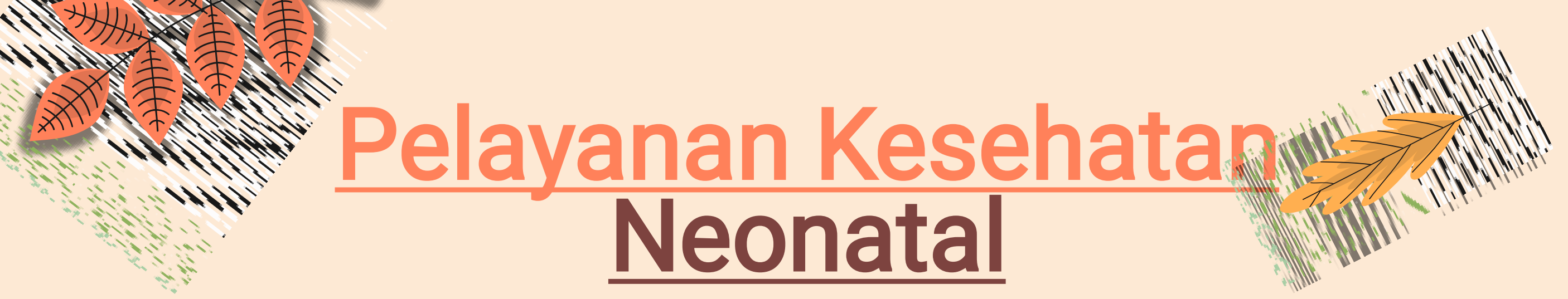

Terdapat dua standar dalam mekanisme pelayanan kesehatan bayi baru lahir yaitu standar kuantitas dan standar kualitas.

Standar kuantitasnya adalah kunjungan neonatal minimal 3 kali, terdiri dari KN1 (6-48 jam), KN2 (3-7 hari), dan KN3 (8-28 hari).

Sedangkan standar kualitasnya terdiri dari pelayanan neonatal esensial saat lahir (0-6 jam) dan pelayanan neonatal esensial setelah lahir (6 jam-28 hari), dimana masing-masing pelayanan meliputi lima macam perawatan 


\section{Kunjungān Neonatus}

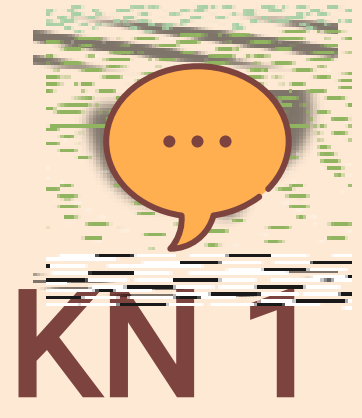

KN1 penting dilakukan untuk mengetahui kondisi pernapasan, warna kulit, keaktifan gerakan, berat badan, panjang badan, lingkar lengan, lingkar dada, serta pemberian salep mata, vitamin $\mathrm{K}$, dan hepatitis $\mathrm{B}$

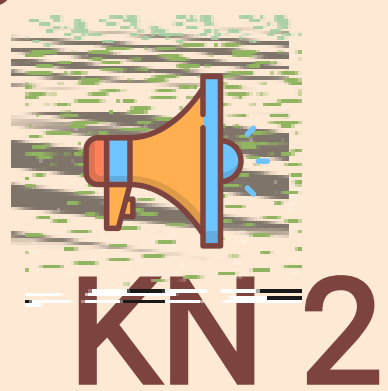

Pelaksanaan KN2 merupakan tahap lanjutan pemeriksaan fisik, penampilan, perilaku bayi, serta pemantauan kecukupan nutrisi sehingga dapat meningkatkan akses neonates terhadap pelayanan kesehatan dasar, mengetahui sedini mungkin bila ada kelainan atau masalah pada bayi menggunakan pendekatan komprehensif MTBM meliputi pemeriksaan tanda bahaya (infeksi bakteri, ikterus, diare, dan berat badan rendah), serta perawatan tali pusat

\section{a
da
s,
ali
we
$=$
$=$}




\section{Pelayanan Kesehatan Anak Yang Baik}

Beda usia, maka beda pula lah penanganan masalah kesehatan yang harus dilakukan oleh dokter. Seperti halnya masalah kesehatan anak, mulai dari baru lahir, anak-anak hingga remaja usia sekitar 18 tahun idealnya ditangani oleh dokter spesialis anak.

Tidak semua penyakit yang dialami seseorang dapat ditangani oleh dokter umum. Dalam arti, pada situasi dan kondisi tertentu karena keterbatasan fasilitas dan kompetensi beberapa penyakit hanya dapat ditangani oleh dokter khusu atau dokter spesialis.
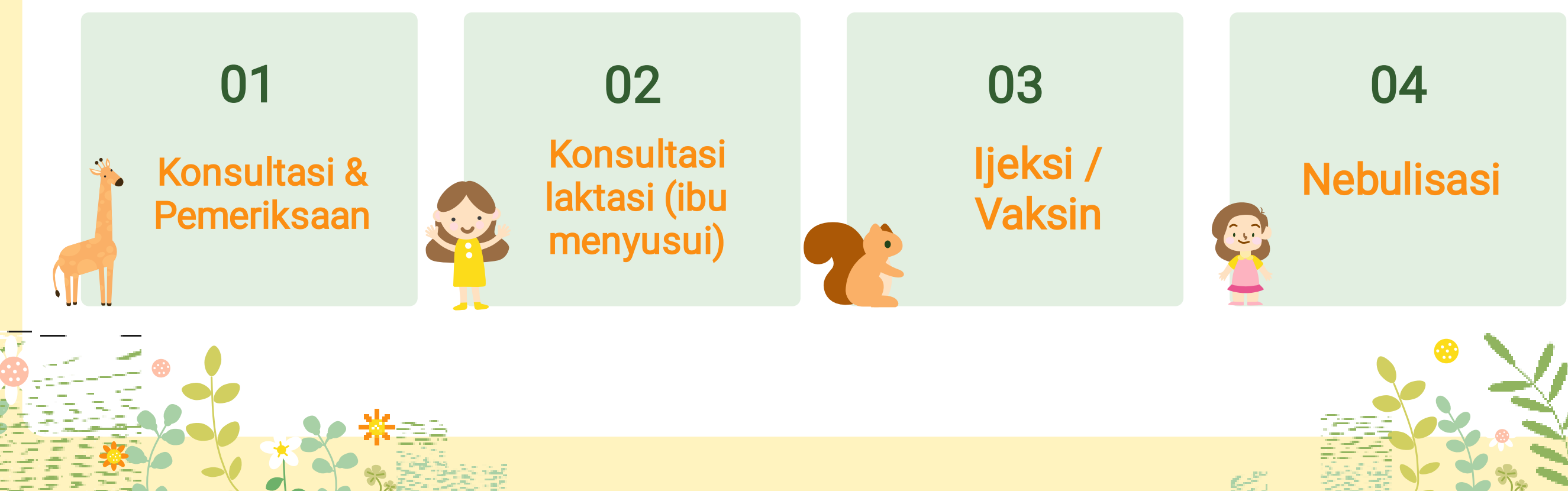


\section{Konsultasi \& Pemeriksaan}

Sebelum dilakukan pemeriksaan kesehatan secara komprehensif, biasanya orangtua pasien melakukan konsultasi terlebih dahulu dengan dokter terkait keluhan atau masalah kesehatan yang terjadi pada anaknya. Dokter akan menggali informasi lebih dalam kepada orangtua pasien agar dapat menegakkan diagnosa sehingga dapat memberikan rekomendasi perawatan atau tindakan medis selanjutnya.

\section{Injeksi / Vaksin}

Vaksinasi adalah imunisasi aktif dengan pemberian vaksin yang dapat merangsang pembentukan imunitas dari sistem imun di dalam tubuh, sehingga membentuk kekebalan atau imunitas tubuh terhadap ancaman penyakit tertentu.

\section{Konsultasi Laktasi (Ibu Menyusui)}

Konsultan laktasi bertugas untuk membantu ibu menyusui yang mengalami kesulitan saat menyusui bayinya. Dengan dukungan dan informasi yang tepat dari konsultan laktasi, proses menyusui pun bisa menjadi lebih mudah.

Untuk apa konsultasi laktasi?

- Meningkatkan percaya diri ibu saat menyusui

- Menurunkan resiko stress yang timbul saat menyusui

- ASI Eksklusif berjalan dengan baik

- Memberikan gambaran bagaimana MPASI yang benar

- Mengetahui masalah selama menyusui

- Menindaklanjuti masalah yang terjadi saat menyusui 


\section{Tanda Bahaya Pada Bayi Baru Lahir}

Tiga "T" Penyebab Bayi Baru Lahir Meninggal

\section{Mengapa penting mengetahui tanda bahaya pada bayi}

baru lahir?

Bayi baru lahir rentan sakit dan kalau sakit cenderung cepat menjadi berat dan serius bahkan bisa meninggal. Gejala sakit pada bayi baru lahir sulit dikenali. Dengan mengetahui tanda bahaya, bayi akan cepat mendapat pertolongan sehingga dapat mencegah kematian

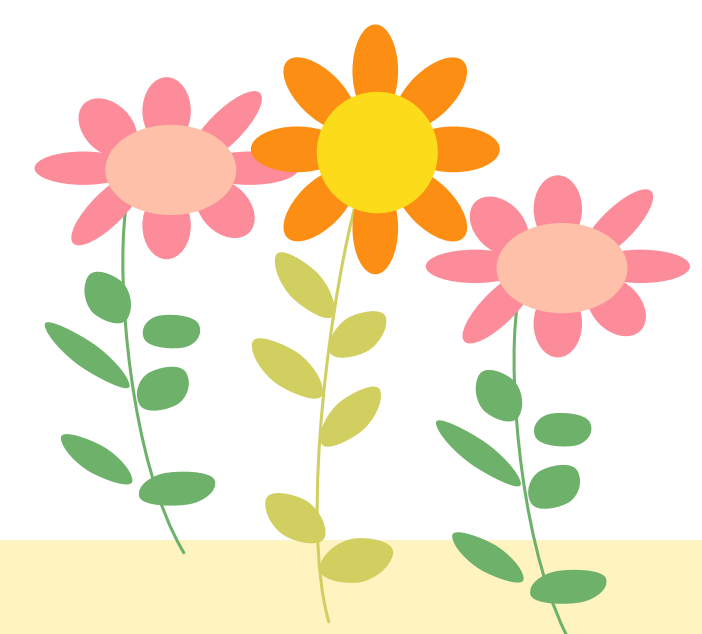

01 Terlambat mengetahui tanda bahaya

02 Terlambat memutuskan untuk membawa bayi berobat ke dokter/ bidan / perawat

$03 \mid \begin{aligned} & \text { Terlambat sampai ke tempat } \\ & \text { pengobatan }\end{aligned}$ 


\section{Tanda Bahaya Pada Bayi Baru Lahir}

1. Tidak mau menyusu atau memuntahkan semua yang diminum, ini tandanya bayi terkena infeksi berat.

2. Bayi kejang: Kejang pada bayi baru lahir kadang sulit dibedakan dengan gerakan normal. Jika melihat gejala/gerakan yang tidak biasa dan terjadi secara berulang-ulang (menguap, mengunyah, menghisap, mata berkedip-kedip, mata mendelik, bola mata berputar-putar, kaki seperti mengayuh sepeda) yang tidak berhenti jika bayi disentuh atau dielus-elus, kemungkinan bayi kejang.

3. Bayi lemah, bergerak hanya dipegang, ini tandanya bayi sakit berat

4. Sesak nafas (frekuensi pernafasan $60 \mathrm{kali} / \mathrm{menit}$ atau lebih)

5. Bayi merintih yang menandakan ia sedang mengalami sakit berat

6. Pusar kemerahan sampai dinding perut, kondisi ini menandakan bahwa bayi mengalami infeksi berat

7. Demam (suhu tubuh lebih dari $37,5 \mathrm{oC}$ ) atau tubuh teraba dingin (suhu tubuh bayi kurang dari $36,5 \mathrm{oC}$ )

8. Mata bayi bernanah banyak, ini dapat menyebabkan bayi menjadi buta

9. Bayi diare, mata cekung, tidak sadar, jika kulit perut dicubit akan kembali lambat. Ini menandakan bayi kekurangan cairan yang berat, bisa menyebabkan kematian

10. Kulit bayi terlihat kuning, kuning pada bayi berbahaya jika muncul pada:Hari pertama (kurang dari 24 jam) setelah lahir, Ditemukan pada umur lebih dari 14 hari, Kuning sampai telapak tangan atau kaki. 
2

PELAYANA

$\mathrm{N}$

NEONATAL ø $\bullet \bullet \bullet$ ESENSIAL

* PADA BAYI 


\section{SETIAP BAYI BARU LAHIR MENDAPATKAN}

PELAYANAN KESEHATAN NEONATAL ESENSIAL SESUAI STANDAR

Pemertrata daerah tingkat kabupaten/kota wajib

memberikan pelayanan kesehatan bayi baru lahir sesuai standar kepada semua bayi usia 0-28 hari di wilayah kerjanya dalam kurun waktu satu tahun

PELAYANAN BAYI BARU

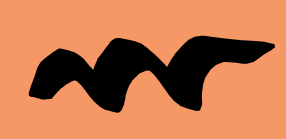
LAHIR SESUAI STANDAR MELIPUTI :

1. Standar Kuantitas

2. Standar Kualitas 


\section{STANDAR}

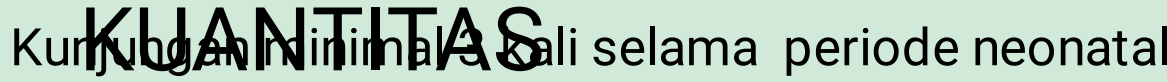

dengan ketentuan :

1.Kunjungan Neonatal 1 (KN1) 6-48 jam

2. Kunjungan Neonatal $2(\mathrm{KN} 2)$ 3-7 hari

3. Kunjungan Neonatal 3 (KN3) 8-28 hari

2.Pelayanan neonatal esensial setelah lahir (6-28 Hari) meliputi :

a.Konseling perawatan bayi baru lahir dan ASI Eksklusif

b.Memeriksa kesehatan dengan menggunakan MTBM

c.Pemberian Vitamin K1 bagi yang lahir tidak difasilitasi Pelayanan Kesehatan atau belum mendapatkan Vitamin $\mathrm{K}$

d.Imunisasi Hepatitis B injeksi untuk bayi usia <24 jam yang lahir tidak ditolong tenaga kesehatan

e.Penanganan dan rujukan kasus neonatal komplikasi

1.Pelayanan neonatal esensial saat lahir (0-6Jam) meliputi :
a. Pemotongan dan perawatan tali pusar
b. Inisiasi Menyusu Dini (IMD)
c. Pencegahan perdarahan (injeksi vitamin K1)
d. Pemberian salep/tetes mata antibiotik
e. Pemberian Imunisasi (injeksi vaksin Hepatitis BO 


\section{Tanda Bayi baru lahir sehat}

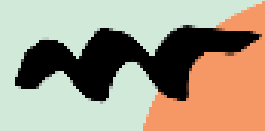

\& 


\section{Bayi Baru Lahir}

TANDA - TANDA BAYI BARU LAHIR SEHAT (UMUR KURANG DARI 1 BULAN)

- Saat bayi lahir bayi langsung bisa menangis

- Seluruh tubuh bayi berwarna merah

- Bayi bisa bergerak aktif

- Bayi bisa menghisap puting susu dengan kuat

- Berat bayi saat lahir $2.500 \mathrm{gr}-4000 \mathrm{gr}$ Suhu bayi $36^{\circ} \mathrm{C}-37^{\circ} \mathrm{C}$ 


\section{DAFTAR PUSTAKA}

Ibrahim, I. A., Syahrir, S., \& Anggriati, T. Faktor-Faktor Yang Berhubungan Dengan Hyperemesis

Gravidarum Pada Ibu Hamil Di RSUD Syekh Yusuf Tahun 2019. Al GIZZAI: PUBLIC HEALTH NUTRITION JOURNAL, 1(2), 59-70. Adha, A.S., Bahtiar, N. W., Ibrahim, I. A., Syarfaini, S., \& Nildawati, N. Analisis Hubungan

Pola Asuh Ibu Dengan Kejadian Stunting Pada Balita Di Kabupaten Jeneponto. Al GIZZAI: PUBLIC HEALTH NUTRITION JOURNAL, 1(2), 71-82.

Amrin Madolan November 13, 2017 Pelayanan Kesehatan Neonatal Esensial berdasarkan PMK Nomor 25 Tahun 2014. JURNAL

KESEHATAN MASYARAKAT (e-Journal) Volume 8, Nomor 1, Januari 2020 
PERAWATAN YANG BAIK PADA BAYI BARU LAHIR

DAN

MANFAAT MEMPELAJARI KESEHATAN ANAK 
Macam-Macam Perawatan Bayi :

\section{Perawatan Tali Pusat}

Keadaan tali pusat harus selalu dilihat untuk memastikan apakah ada perdarahan atau tandatanda infeksi (kemerahan dan terdapat pus). Bila tidak terlihat adanya kemerahan pada tali pusat, maka sering kali klem tali pusat dilepas pada hari ke 3 . puntung tali pusat akan lepas sendiri setelah mengalami proses nekrosis menjadi kering pada hari ke-6 sampai hari ke-8. Tali pusat tidak boleh ditutup rapat dengan menggunakan apapun, karena akan menyebabkan tali pusat menjadi lembab. selain memperlambat lepasnya tali pusat, penutup tali pusat juga akan menyebabkan resiko infeksi. Bila terpaksa ditutup, menutup atau mengikat tali pusat secara longgar dengan kasa kering steril.

Pada perkembangan bayi, setelah tali pusar lepas, dibutuhkan waktu sekitar 7-10 hari untuk sembuh sepenuhnya. Antara 5-15 hari setelah bayi lahir, sisa tali pusar akan mengering, menjadi hitam, dan kemudian akan lepas dengan sendirinya.

\section{PERAWAATAN YANG BAIK PADA BAYI YANG BARU LAHIR}

Bayi baru lahir (BBL) sangat rentan terhadap infeksi yang disebabkan oleh paparan virus dan kuman selama proses persalinan maupun beberapa saat setelah lahir. Perawatan BBL yang tidak tepat dapat menimbulkan masalah kesehatan pada bayi sampai kematian. Kesalahan tersebut dikarenakan kurangnya pengetahuan dan kesianan ibu dalam 


\section{LANGKAH-LANGKAH PERAWATAN TALI PUSAR}

- Cucilah tangan terlebih dulu ketika akan membersihkan tali pusar bayi menggunakan sabun antiseptik dan juga air yang mengalir.

- Gunakan kain yang lembut dan juga air hangat untuk mencegah infeksi. Jika pada saat memandikan si Kecil tali pusarnya terkena air, maka harus segera mengeringkannya menggunakan kain kasa. Caranya cukup membersihkannya menggunakan air hangat dan kain lembut atau kain yang dapat menyerap air. Setelah itu, keringkanlah tali pusar bayi agar tidak terjadi infeksi akibat lembap dan kuman yang menempel.

- Agar cepat kering dan lepas, sebaiknya tali pusar bayi tidak dibungkus dengan apapun. Hal tersebut bertujuan agar udara dapat masuk dan akhirnya tali pusar mengering dengan sendirinya lalu terlepas.

- Gunakan baju yang sedikit longgar agar tidak mengganggu tali pusar bayi yang belum kering.

- Saat memandikan si Kecil, cukup gunakan waslap untuk membasuh area tubuhnya. Hal tersebut dimaksudkan untuk menjaga tali pusar bayi agar tidak terkena air terlalu banyak dan menjaga agar tali pusar bayi tetap kering. 


\section{Kebutuhan Personal Hygienis}

a. Memandikan

Memandikan bayi merupakan upaya yang dilakukan untuk menjaga agar tubuh bayi bersih, terasa segar, dan mencegah kemungkinan adanya infeksi. Prinsip dalam memandikan bayi yang harus diperhatikan adalah menjaga jangan sampai bayi kedinginan serta kemasukan air ke hidung, mulut atau telinga yang dapat mengakibatkan aspirasi.

\section{Cara Memandikan Bayi sangatlah susah-susah-gampang. Berikut adalah langkah- langkah cara} memandikan bayi:

- Siapkan ruangan. Harus yang hangat dan bersih, letakkan bak di permukaan yang rata dan stabil, seperti meja, agar kita merasa nyaman saat memandikan bayi.

- Siapkan semua peralatan mandi. Siapkan handuk, waslap, sabun, krim bayi dan pakaian bersih, pastikan semua peralatan mandi mudah dijangkau saat memandikan.

- Tuangkan air di bak mandi bayi. Air sebaiknya cukup sampai dan dapat menutupi bahu bayi saat dimandikan. Gunakan sabun khusus bayi yang lembut dengan pH seimbang, yang cocok untuk kulit bayi.

- Cek temperature air . Air untuk mandi sebaiknya jangan terlalu hangat, dan juga jangan terlalu dingin, cara untuk mengujinya yaitu dengan lengan atau siku Bunda. Jangan menuangkan air lagi setelah bayi sudah berada didalam air.

- Lepaskan pakaian bayi dengan hati-hati dan tahan leher dan kepalanya dengan lembut, serta masukan bayi di bak dan air mandi yang sudah disiapkan.

- Mandikan bayi, basuh si bayi dengan air secara lembut dengan satu tangan dan perlahan mulai dari atas kepala, leher dan yang lainnya. Pastikan Bunda membasuh di semua lipatan, termaksud di bawah dagunya. Basuh bagian bawah bayi pada saat terakhir. Jangan memandikan si bayi lebih dari 5 menit 
- Angkat si bayi dengan lebut dan hati-hati saat keluar dari bak mandi dan langsung selimuti bayi dengan menggunakan handuk lembut, kemudian keringkan tubuh bayi dengan perlahan dan lembut.

- Oleskan krim lotion yang berfungsi untuk melembabkan kulit bayi yang sangat kering seperti di area popok. Bunda bisa memilih krim yang khusus bayi, juga gunakan bedak untuk membantu menyerap keringat si bayi agar tidak terjadinya biang keringat. Setelah itu, gunakan minyak telon plus untuk menjaga bayi, agar tubuh bayi tetap hangat sekaligus melindungi bayi dari gigitan nyamuk yang menganggu.

- Setelah itu, pakailah pakaian yang sudah disiapkan. Selesai, bayi pun bersih, dan wangi.

Bayi butuh mandi dua kali sehari. Memandikan bayi sebelum 40 hari bukan masalah. Bayi yang lahir setelah 6 jam sudah boleh dimandikan. Pagi hari bayi yang baru lahir atau bulan-bulan pertama bisa dimandikan antara jam 07:00, 08:00 dan sampai jam 09:00 pagi, sedangkan pada sore hari pukul 14:00 dan. Sebaiknya bayi dimandikan dua kali dalam sehari

\section{b. Kebersihan Popok}

BAB (Buang Air Besar) hari 1-3 disebut mekoneum yaitu feces berwana kehitaman, hari 3-6 feces tarnsisi yaitu warna coklat sampai kehijauan karena masih bercampur mekoneum, selanjutnya feces akan berwarna kekuningan. Segera bersihkan bayi setiap selesai BAB agar tidak terjadi iritasi didaerah genetalia.

Bayi baru lahir akan berkemih paling lambat 12-24 jam pertama kelahirannya, BAK (Buang Air Kecil) lebih dari 8 kali sehari salah satu tanda bayi cukup nutrisi. Setiap habis BAK segera ganti popok supaya tidak terjadi iritasi di daerah genetalia.

\section{c. Merawat Kulit}

Kulit bayi sangat rentan terhadap gangguan kulit hal ini disebabkan karena sensitifnya kulit bayi. Untuk itu diperlukan adanya perawatan yang cermat terhadap kulit bayi. Ketidakcermatan dalam perawatan kulit bayi dapat menyebabkan berbagai gangguan terhadap kulit bayi yang disebabkan oleh biang keringat atau ruam popok. 
ASI Eksklusif adalah bayi hanya diberi ASI saja, tanpa tambahan cairan lain, seperti susu formula, jeruk, madu, air teh, air putih dan tanpa tambahan makanan padat seperti pisang, pepaya, bubur susu, biskuit, bubur nasi dan tim. Lama pemberian ASI Eksklusif adalah sampai bayi berumur 6 bulan, setelah 6 bulan, bayi mulai diberi makanan pendamping $\mathrm{ASI}$, sedangkan ASI dapat diberikan sampai 2 tahun atau lebih.Pemberian mineral, vitamin, maupun obat boleh diberikan dalam bentuk cair sesuai anjuran dokter.

\section{PEMBERIAN ASI}

Menurut sebuah studi yang dilakukan oleh JAMA Pediatrics menunjukkan bahwa menyusui eksklusif selama 6 bulan bisa mengurangi risiko leukimia pada anak sampai $20 \%$. ASI memiliki kandungan yang bisa menambah system kekebalan tubuh bayi.Tidak ada aturan khusus berapa kali bayi bayi harus disusui. Akan tetapi bila dikira-kira, bayi butuh menyusu antara 8-12 kali sehari atau setiap 1-3 jam. Volume lambung bayi masih sangat kecil justru kurang memungkinkan bayi menyusu lebih sering dari itu.Memberikan ASI eksklusif haruslah tepat untuk mendapatkan hasil yang optimal bagi bayi. Cara terbaik memberikan ASI eksklusif adalah dengan teknik latch on. Latch on adalah posisi ketika bayi menyusu dengan mulut melekat pada payudara ibu. Teknik ini membantu bayi menerima ASI secara memadai 


\section{MANFAAT MEMPELAJARI KESEHATAN ANAK}

Bagi seorang ibu tentunya sangat penting mempelajari kesehatan anak karena pada usia ini merupakan masa pertumbuhan dan perkembangan fisik serta mental anak. Sehingga anak masih sangat rentan terhadap berbagai keluhan atau gangguan kesehatan baik jasmani maupun rohani. Sehingga orang tua wajib mempelajari kesehatan anak sehingga tidak akan mempengaruhi pembentukan karakter anak di kemudian hari.

Sehat juga dapat diartikan sebagai keadaan baik dan bebas dari penyakit. Sehingga untuk mewujudkan kondisi ini, diperlukan asupan gizi yang cukup. Gizi merupakan kebutuhan yang sangat penting dalam proses pertumbuhan, dan perkembangan otak, membangun sistem kekebalan tubuh yang kuat.

Jadi kesehatan anak dan gizi sangat berhubungan. Menyiapkan asupan gizi untuk anak merupakan hal yang penting untuk diperhatikan oleh orangtua. Karena asupan gizi yang diterima anak akan memengaruhi proses tumbuh kembang mereka di usia dewasa kelak. Salah satu kebutuhan gizi yang harus di sediakan orang tua dari anak masih bayi yaitu MP-Asi dan makanan bergizi lainnya saat anak menginjak usia dewasa. 


\section{Daftar Pustaka}

Purba, D. H., Kartika, L., Supinganto, A., Hasnidar, H., Wahyuni, W., Sitanggang, Y. F., ... \& Hutapea, A. D. (2020). Ilmu Kesehatan Anak. Yayasan Kita Menulis.

Arimbawa, I. W., Dewi, K. A. T., \& bin Ahmad, Z. (2016). Hubungan Faktor Perilaku dan Faktor Lingkungan terhadap Kejadian Diare pada Balita di Desa Sukawati, Kabupaten Gianyar Bali Tahun 2014. Intisari Sains Medis, 6(1), 8-15.

Jayadi, Y. I., \& Rakhman, A. (2021). Evaluasi Program Pemberian Makanan Tambahan (MT) Anak Balita Pada Masa Pandemi Covid 19. Poltekita: Jurnal Ilmu Kesehatan, 15(2), 105-117.

Hosang, K. H., Umboh, A., \& Lestari, H. (2017). Hubungan pemberian makanan tambahan terhadap perubahan status gizi anak balita gizi kurang di Kota Manado. e-CliniC, 5(1)

Septikasari, M. (2018). Status gizi anak dan fa

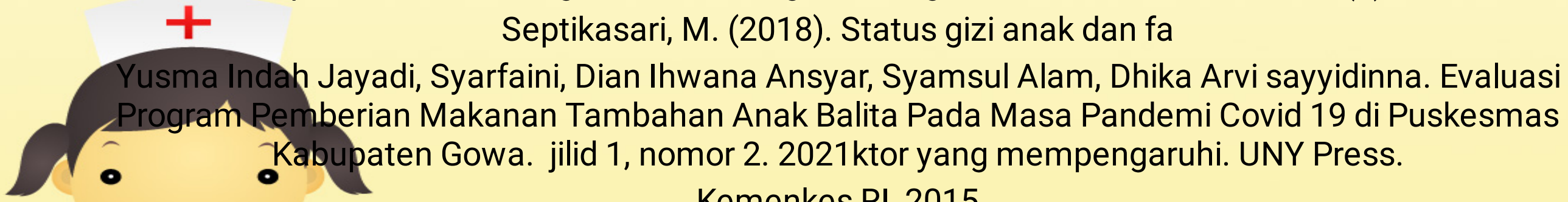

Kemenkes RI, 2015 


\section{Daftar pustaka}

Sudarmañ, S., Aswadi, A., Syamsul, M., \& Gabut, M. (2021). Faktor Yang Berhubungan Dengan Kejadian Stunting Pada Balita di Wilayah Kerja Puskesmas Pannambungan Kota Makassar. Al GIZZAl: PUBLIC HEALTH NUTRITION JOURNAL, 1(1), 1-15.

Kementerian Kesehatan Republik Indonesia. (2010). Buku Saku Pelayanan Kesehatan Neonatal Esensial: Pedoman Teknis Pelayanan Kesehatan Dasar. Jakarta

Rohana, A., Sriatmi, A., \& Budiyanti, R. T. (2020). Pelaksanaan Pelayanan Neonatal Berdasarkan Standar Pelayanan Minimal Kesehatan Bayi Baru Lahir Di Puskesmas Dukuhseti Kabupaten Pati. Jurnal Kesehatan Masyarakat (Undip), 8(1), 97-106.

Kementrian pendidikan dan kebudayaan . (2020). Menjaga Kesehatan Anak Usia Dini.

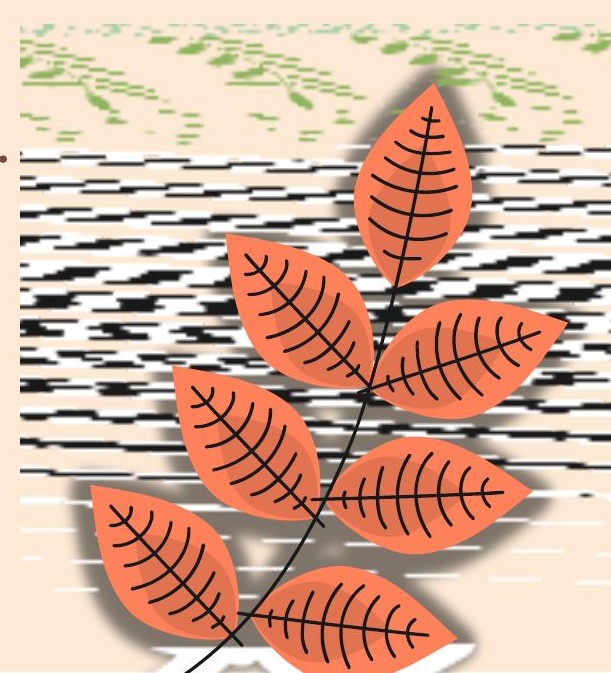




\section{DAFTAR PUSTAKA}

1) Trihono, P. P., Windiastuti, E., Pardede, S. O., Endyarni, B., \& Alatas, F. S. (2013). Pelayanan Kesehatan Anak Terpadu.

2) Jayadi, Y. I., Syarfaini, S., Ansyar, D. I., Alam, S., \& Sayyidinna, D. A. Evaluasi Program Pemberian Makanan Tambahan Anak Balita Pada Masa Pandemi Covid 19 di Puskesmas Kabupaten Gowa. Al GIZZAI: PUBLIC HEALTH NUTRITION JOURNAL, 1(2), 89-102.

3) Kopa, M. T. A. I., Togubu, D. M., \& Syahruddin, A. N. Hubungan Pola Pemberian MPASI dengan Status Gizi Anak Usia 6-24 Bulan di Kabupaten Pangkep. Al GIZZAI: PUBLIC HEALTH NUTRITION JOURNAL, 1(2), 103-110.

4) Karawang, Hermina. 2020. Mengapa Harus Konsultasi Laktasi?

5) Rsud. 2017. Kenali Tanda-tanda Bahaya Pada Bayi Baru Lahir.

6) dr. Chandni P. Daryanani, Sp.A. 2020. Pelayanan Kesehatan Anak.
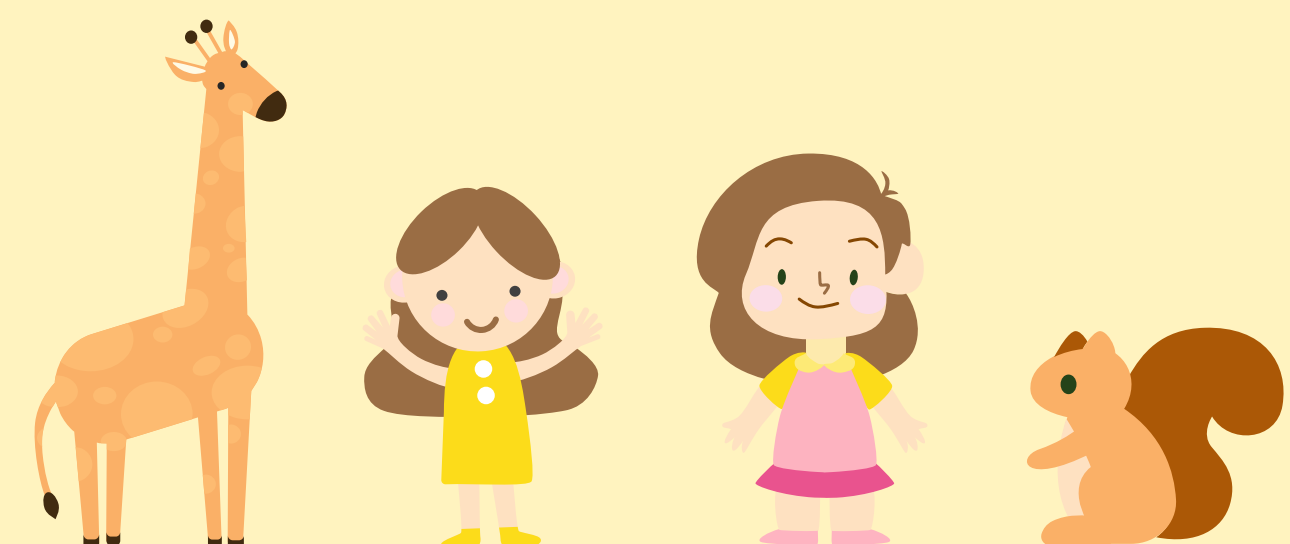


\section{Daftar Pustaka}

Wasiah, A., \& Artamevia, S. (2021). Pelatihan Perawatan Bayi Baru Lahir. Journal of Community Engagement in Health, 4(2), 337-343.

Saragih, J. E. D. (2020). GAMBARAN PERILAKU IBU NIFAS DALAM PERAWATAN BAYI BARU LAHIR DI WILAYAH KERJA KLINIK BERSALIN PRATAMA CITRA MARINDAL KABUPATEN DELI SERDANG TAHUN 2019.

Kopa, M. T. A. I., Togubu, D. M., \& Syahruddin, A. N. Hubungan Pola Pemberian MPASI dengan Status Gizi Anak Usia 6-24 Bulan di Kabupaten Pangkep. Al GIZZAI: PUBLIC HEALTH NUTRITION JOURNAL, 1(2), 103-110.

Jayadi, Y. I., Syarfaini, S., Ansyar, D. I., Alam, S., \& Sayyidinna, D. A. Evaluasi Program Pemberian Makanan Tambahan Anak Balita Pada Masa Pandemi Covid 19 di Puskesmas Kabupaten Gowa. Al GIZZAI: PUBLIC HEALTH NUTRITION JOURNAL, 1(2), 89-102. 
THANK YOU@: 